\title{
SUDANIC AFRICA
}

\section{A Journal of Historical Sources}

VOLUME 3

\section{Contents include}

From Slaves to Coolies. Two Documents from the Nineteenth-century Somali Coast,

Lidwien Kapteijns \& Jay Spaulding

Sons of a Hidden Imām. The Genealogy of the Mirghani Family, Albrecht Hofheinz A Sultanic Charter from Sinnär. Anders Bjorkelo \& Ahmad Ibrahim Abu Shouk The Capitulation of the Omdurman Notables, Robert Kramer A Prince and his Neighbours, R.S. O'Fahey

A Letter from the Amir of Mafara to the Amir of Zamfara, John $O$ Hunwick A Letter from Ki-Toro Mahamman Gaani. King of Busa, about the "Kisra" Stories of Origin (c. 1910), P.F. de Moraes Farias

An Alleged Charter of Privilege issued by Askiya al-hāij Muhammad to the descendants of Mori Hawgāro, John O. Hunwick

Also: BIBLIOGRAPHIES, NOTES AND COMMUNICATIONS, BOOK REVIEWS.

Subscriptions: $\$ 10.00$ or $₫ 6.00$ (individuais)

$\$ 15.00$ or $\$ 10.00$ (institutions)

Payable in dollars on U.S. banks oniy to:

SUDANIC AFRICA.

c:o J. O. Hunwick.

Department of History,

Northwestern University,

Evanston. IL 60208-2200

U. S. A.
Payable in Pounds Sterling to: SUDANIC AFRICA. c/o Knut Vikør.

Center for Middie Eastern \& Islamic Studies

University of Bergen.

N-5007 Bergen. Norway

zubilsnea by the Centre for Middle Eastern and Islamic Studies. University of Berçen. Norway

Editors: A.S. OFanev Knut Vikax, john O - -unwick, Jav Spaulding 


\section{CAHIERS D'ÉTUDES AFRICAINES}

A Quarterly Journal

Measuring differences:

Physical anthropology

\section{scholars and berbers}

- L'impossible objet de la raciologie. Prologue à une anthropologie physique du Nord de l'Afrique (G. Boëtsch \& J.-N. Ferrié)

- La classification raciale de l'Afrique du Nord au début du $\mathrm{XIX}^{\mathrm{e}}$ siècle (A. Thomson)

- Simplification ethnique en Afrique du Nord : Maures, Arabes et Berbères (XVIII ${ }^{\mathrm{e}}-\mathrm{XX}^{\mathrm{e}}$ siècles) (F. Pouillon)

- Classifications linguistiques et anthropologiques de la Société d'anthropologie de Paris au XIX' siècle (K. Haoui)

- Égypte noire et Berbérie blanche. La rencontre manquée entre la biologie et la culture (G. Boëtsch)

- Préhistoire et protohistoire en Algérie au XIX' ${ }^{\mathrm{e}}$ siècle : les significations du document archéologique (N. Coye)

- La naissance de l'aire culturelle méditerranéenne dans l'anthropologie physique de l'Afrique du Nord (J.-N. Ferrié)

\section{pygmies}

- L'invention des Pygmées (S. Bahuchet)

Editorial Office: EHESS, 54 boulevard Raspail, 75006 Paris

Subscriptions: Centrale des Revues, 11 rue Gossin, 92543 Montrouge Cedex

Sales: CID, 131 boulevard Saint-Michel, 75005 Paris

ÉDITIONS DE L'ÉCOLE DES HAUTES ÉTUDES

EN SCIENCES SOCIALES . PARIS 


\section{THE JOURNAL OF \\ AFRICAN HISTORY

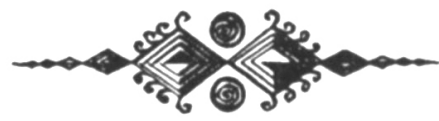

"This is the basic and recognised journal in the field of African History...very useful and substantial book review section..."

Magazines for Libraries

The Journal of African History, established in 1960, publishes articles and reviews which range over the African past from the beginnings of food production to the $1960 \mathrm{~s}$. In recent years there has been much emphasis on economic history and on African politics in the later colonial period, while the journal has also explored several themes of growing interest to historians of other regions:

- gender roles

- demography

- health and hygiene

- propaganda

- legal ideology

- labour histories

- nationalism and resistance

- custodial institutions

- the construction of ethnicity

- ideas of time

- photographs as historical sources

- slavery and the slave trade

- the interpretation of oral tradition

\section{Order Form}

| Please enter my subscription to The

Journal of African History Volume 34, 1993 (ISSN 0021-8537) @

( $\square$ institutions $£ 58$

$\square$ individuals $£ 31$

| $\square$ students $£ 25$

I $\square$ Please send by airmail @ $£ 13$ per year extra

$\square$ Please send me an invoice

Name

Address

Send your order to: Journals Marketing

Department, Cambridge University Press, FREEPOST*, The Edinburgh Building,

Cambridge CB2 IBR, UK

Tel: +44 (0)223325806 Fax: +44 (0)223 315052

( ${ }^{*}$ no postage stamp necessary if posted in UK)

In USA, Canada \& Mexico write to: Cambridge University Press, 40 West 20th Street, New York, NY IOOII-42II, USA

|

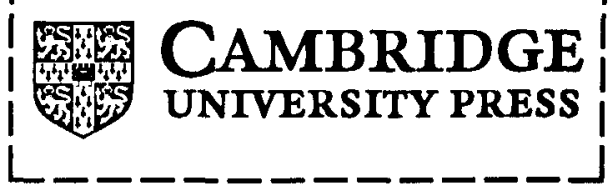


